Koch, Andrew M. "Immanuel Kant, The Right of Necessity, and the Liberal

Foundation of Social Welfare" Southeastern Political Review, 20: 2 (Fall 1992)

295-314.

(ISSN: 0730-2177) DOI: 10.1111/j.1747-1346.1992.tb00312.x [Journal continued by

Politics and Policy] Version of record (Wiley-Blackwell) at:

http://www3.interscience.wiley.com/

\title{
IMMANUEL KANT, THE RIGHT OF NECESSITY, AND THE LIBERAL FOUNDATION OF SOCIAL WELFARE
}

\author{
Andrew M. Koch
}

\section{Introduction}

Liberal theory asserts that the state's primary responsibility is the security of its citizenry. The social contract is created, to borrow from Locke, in order to secure life, liberty, and property. This responsibility of the state stands above all others within the liberal tradition.

Modern liberal theory also suggests that the law, as a rational codified body of prohibitions, is designed to deter the aggressive or violent acts that may occur as rational actors pursue their self interest in a social environment. The state performs its security function by codifying a set of rationally conceived laws and by being prepared to enforce those laws. The threat of state sanctioned violence is always present to deter those who would violate its prohibitions.

In 1989 there were 18,954 people murdered in the United States. This is the case even though the United States has the toughest possible penalty for the crime of murder: physical extermination at the hands of the state. The high rate of homicide in the United States suggests that the threat of even the most severe form of punishment is ineffective as a deterrent to violence.

This paper will explore the writings of Immanuel Kant on the state's role within the social contract and his comments regarding the requirements for the effective functioning of the law. It will be argued that within the writings of Kant a liberal justification for the welfare state can be developed based on his ideas about the state and its responsibilities. More specifically, the paper will focus on the role a condition termed "necessity" has on the state's ability to provide security for the population. Necessity represents a condition in which a person perceives that his or her survival is threatened. Kant claimed that action taken out of necessity lies outside the arena of human behavior in which the law can have an effective deterrent value.

Given the state's responsibility to provide for the security of the citizens, it must seek to eliminate necessity as a motivation for human behavior. Social welfare is essential to that task. Welfare assists in providing food, clothing, and shelter to those who would otherwise find themselves lacking these basic human needs. Welfare removes economic necessity as a motivation for human behavior. It is essential in providing the conditions that support the effective functioning of the law. Welfare, therefore, is vital to the state fulfilling its security role within the liberal definition of the state. 
If we take Kant's assertion seriously, he provides a rational justification for the welfare state outside of the prevailing discussion of who is responsible for the poverty of the poor. While it will be suggested that the responsibility question falls within the prevailing political culture in the United States, it will also be argued that the question of responsibility is an irresolveable ontological issue. It is not, therefore, the most important question to be addressed by the state.

By moving the debate away from the question of responsibility, Kant refocuses the welfare debate to the question of the state's responsibility under the social contract. This is particularly important at a time when welfare in the United States has been under attack by neoconservatives, who see the state's security function being served by a combination of dogmatic indoctrination and law enforcement.

Kant offers an alternative. Welfare enhances the security of the population by increasing the likelihood that the threat of punishment implied by the law will be an effective deterrent to crime. The result, according to this reasoning, is that everyone in society has their security enhanced by the state's commitment to social welfare.

\section{Welfare and Responsibility}

\section{A. Individualism and American Political Culture}

In the United States the attacks on the welfare state take place in a social and political climate that is clearly different than other Western democracies. Historically, the United States has not had either strong organic conservatism on the right or a viable socialist movement on the left. Either of these political philosophies would provide an ethical basis for social welfare. Both of these traditions emphasize collective responsibility within a social context.

The United States, however, has neither of these political traditions. Instead, two powerful ideas form the core of the American political culture. First, from the liberal ideology of Locke, comes the identification of "freedom" with the lack of government intervention in the lives of individuals. Second, from the Protestant tradition comes a strong emphasis on individual accountability. This second aspect of American culture Stephen Kalberg identifies as stemming from a world oriented asceticism that characterizes the American sects of Protestantism. (Kalberg, 1991, p. 41.) This form of Protestantism identifies the individual as the sole agent of moral choice. Even as the self conscious origins of this belief have faded in the Twentieth Century, the idea that the individual is responsible for mastering the impulsive, pleasure seeking components of the human character remains. (Kalberg, 1991, p. 40.) Individual moral agency coupled with the myth and reality of the pioneer ethos for self reliance produced a political culture antithetical to the notion of state sponsored welfare programs.

As Kalberg points out, when the Protestant roots of this form of individualism began to fade with the rise of industrialization the result was a philosophic individualism that sought to ground itself in science. Out of this intellectual orientation in the United States came the doctrine of Social Darwinism. (Kalberg, 1991, 42.) Social Darwinism justified the most radical form of individualism, stressing the "unnatural" and damaging character of social assistance to the poor. (Sumner in Dolbeare, 1984, 341-356.) In addition, it is not necessary because the rich indirectly help the poor by creating jobs. The poor must take responsibility for their condition of poverty. (Sumner in Levi, 1988, 325.) It is not the role of government to engage in redistributive efforts to assist the poor.

With the identification of individual action as the means to the public good and the perception that freedom from government action is the most desirable political condition, the activities of the "state" and "society" are effectively separated. The minimal state has only the 
function of protecting the public order, largely defined as private property and personal security. All other matters are to be left to the social system and its voluntary organizations. This reasoning suggests that welfare acquires the character of social charity, which is best left outside of the minimalist conception of the state.

Within this scheme, the privatization of welfare is a logical outcome. The "society" has the function of providing for those in need. The government is devoid of ethical responsibility in the welfare process. The state is removed from the process with the expectation that the cultural imperative supporting charity will then engage. The "do-gooders" are not to be eliminated in the society, they are simply to be removed from government.

Two themes continue to be fused. A society of voluntary associations is best able to handle any charity function needed by society, and that the minimal government serves the best interests of society. In a 1931 speech Herbert Hoover stressed these themes, while still echoing the ascetic Protestant conception that individual acts of giving will improve the moral character of society.

...if we break down this sense of responsibility

of individual generosity to individual and mutual

self help in the country in times of national difficulty and if we start appropriations of

this character we have not only impaired something

infinitely valuable in the life of the American

people but have struck at the roots of self-

government. (Hoover in Levy, 1988, p. 395.)

The state has an imperative not to intervene. In an argument reminiscent of Aristotle, Hoover argues that individuals with the means must be given the opportunity to improve their character by giving. If the state were to take over this role from the society, the morality of the society would be adversely affected.

Despite this individualistic ethos, some social legislation was passed in the 1930's, including the Social Security Act of 1935. Did this mark the end of America's anti-government political culture? The philosophic orientation in favor of minimal government and individualism had not waned. As Colin Gordon suggests, the modest social legislation in the 1930's was generated by the demands of the business community in their desire to "spread out" the costs of workers compensation and unemployment insurance. (Gordon, 1991, 166.) The 1930's did not signify a transformation in the political culture of the United States.

The anti-state and anti-welfare orientation remains an intellectual undercurrent in American politics today. It is in this context that the debate between the politcial right and the left is taking place in the United States over who is morally responsible for the poverty of the poor. The right criticizes the proponents of social welfare for not blaming the individual for his or her condition of poverty. To the neoconservatives the government then has a dual role of both forcing compliance and rewarding "good citizens." Using a Hobbesian view of human nature, both Lawrence Mead (1986) and Charles Murry, (1984) suggest that for those who are not sufficiently motivated by the economic systems appeals to self-interest, a stick may justifiably replace the carrot to ensure "order" and "obedience." One of the major problems in the welfare system, the reader is reminded, is the fear of blaming the victims for their condition of poverty. As Lawrence Mead puts it, "government must persuade them [welfare recipients] to blame themselves." (Mead 1986, 10) 
The conceptual differentiation between "state" and "social" responsibilities in the welfare debate secures the sanctity of the individual. Welfare becomes a matter of individual conscience. The individual donor to charity can be labeled as "good" for making a contribution in conformity with the doctrine of "brotherhood." The welfare recipient, on the other hand, is labeled as "bad" for not taking personal responsibility for his or her own condition. The ideal is for the state simply to provide law and order as the interaction of the "good" and the "bad" takes place in the larger society.

In the political arena this ideology reflects the direction of public policy. The call by Ronald Reagan to return welfare to private charities and churches clearly represents the view that the state does not share welfare responsibilities. The Bush "thousand points of light" strategy reflects these same liberal roots within what is now termed the American neoconservative tradition.

The ideological left has come to a somewhat different conclusion in their analysis. On the left the debate has focused on the structural nature of poverty. In this characterization, the unemployment that leads to poverty and the creation of an underclass is seen as a result of a declining demand for unskilled and semi-skilled workers. Increases in the use of high technology in domestic production, coupled with increasing dependence on foreign sources of low technology commodities has exacerbated the plight of the poor. When international capital and production transfers are added to the structural inequality already present within the capitalist form of economic relations, the poor are portrayed as victims of conditions beyond their control. The personal responsibility of the poor for their poverty is effectively diminished. The poor are the casualties of the industrial order.

The analyses of both the right and the left focuses on the question of "who" is responsible for the conditions of poverty. The debate asks, "why are people poor?" The political right wants to blame the victims, the left wants to blame the institutional structure.

However, the blame approach to the welfare issue is doomed to perpetual deadlock due to the character of the question being addressed. The conclusions with regard to "who" bears responsibility for the creation of poverty will depend as much on the assumptions and values of the investigator as any objective structural features of economic practice. If one accepts the Hobbesian view of human nature, that human beings are selfish, lazy, and immoral by nature, then one may logically conclude that only fools or saints give freely to such unworthy creatures. If, however, one has a more benign view of human essence, the conclusion will be different. If an individual's character is a product of the social and economic context then social and political responsibilities conjoin and the state's welfare role is certain.

The normative and ontological assumptions regarding human nature and personal responsibility relegate this debate to an irresolveable and subjective clash of world views. In the final analysis, however, there is no way of deciding the ontological questions raised by this level of debate. Both arguments rely on assumptions about human nature and the extent to which the individual's life prospects are deterministically linked to the economic environment. The debate over social welfare can, therefore, never be resolved on this level.

\section{B. Refocusing the Welfare Debate}

The purpose of this paper is not to argue the relative merits of "who" is responsible for the impoverishment of the poor. Both the ideological right and the left have become immersed in a debate that has ignored another critical issue in the discussion of social welfare policy. The existing debate centers around the issue of how responsible the individual is for his or her economic 
condition. It is, therefore, ultimately a question of how accountable government can hold that individual.

However, the welfare debate also needs to address government's responsibilities in a free society. What are the civic and political responsibilities of government if it wishes to hold people morally and legally accountable for their actions? To put this question another way, 'what conditions must be present if the state, as a legitimate agent of coercion, wishes to hold people accountable for their actions through a system of laws?' What conditions must be present if the state is to be effective in the pursuit of freedom and political stability? This is precisely the issue which is missed by a debate that centers solely on the question of individual responsibility. The state has a responsibility to create conditions in which laws can be effective. This responsibility can be met only if the state is capable of providing the conditions required for the citizens to obey the law.

The elimination of "necessity" as a motivation for action is one such condition required for the legal system to effectively maintain order. In the writings of Immanuel Kant the "right of necessity," or the right to take whatever action is necessary to save your own life, concerns a set of actions against which no legal prohibitions or threats can have any effect. "Necessity," therefore, is a circumstance of action which weakens the ability of the state to function as an effective unit for the administration of justice.

Social welfare, therefore, constitutes a fundamental condition necessary for the effective functioning of the legal order. Anyone who is faced with the problems of physical survival cannot be expected to refrain from doing whatever is necessary in order to ensure continued existence. Therefore, welfare is not a luxury to the modern state. It is an absolutely essential element for ensuring the state's survival, regardless of "who" is responsible for the conditions which cause poverty.

In civil society individuals interact in an institutional context. Governmental and legal institutions are designed to maintain order and stability. The maintenance of an effective system of laws is essential to that order. Therefore, while it may be true, as Sheldon Wolin (1987) and others have argued, that social welfare has the consequence of expanding state power, it also has another consequence. Welfare assists in the elimination of "necessity" in social interaction and thereby enhances the deterrent function of the punitive measures enacted by the state. The state cannot expect compliance with its laws unless the conditions for compliance are present. This can only be assured if "necessity" is eliminated as a justification for action in the social environment.

\section{Kant, "Necessity," and Justice}

\section{A. Conceptions of "Necessity" in Political Philosophy}

Various forms of the concept of necessity can be found in political philosophy going back to Ancient Athens. Aristotle acknowledged that one of the causes of crime "results from a lack necessities." (Aristotle 1977, 65) To remedy this sort of crime Aristotle suggested that a "modicum" of property and some sort of work be provided to those who find themselves in want. (Aristotle 1977, 65) Aristotle does not here explore the causes of want, only the political response required to eliminate the negative social consequences of this condition.

The problem of need is also taken up by St. Thomas Aquinas in Summa Theologica. According to St. Thomas, natural and positive law prohibit the taking of another person's private property. This is a central proposition if civil society is to be maintained. However, St. Thomas recognized a right of necessity in his qualification of this prohibition. It is neither theft nor robbery 
to take something out of need. (St. Thomas Aquinas, Summa Theologica, II-II, Q. 66, Art 4.) While taking something out of need may be harmful to another, and may produce a disintegrating effect on society, it cannot be subject to moral condemnation. Necessity overrides the other considerations.

The legal implications of the right to self preservation are also explored by Thomas Hobbes. The right of the subject to preserve his or her own life overrides even the legitimate legal claims of the state.

... if the sovereign command a man, though justly condemned, to kill, wound, or maim himself, or not to resist those that might assault him, or to abstain from

the use of food, air, medicine, or any other thing without which he cannot live, yet has that man the liberty to disobey. (Hobbes 1978, 176)

Even in Hobbes, where order and obedience to authority have a central role, the individual has a right to resist all that would take the subject's life. This is true even if the protective action violated the legitimate legal claims of the sovereign.

In the writings of these three authors, and others, there is a normative assertion about a person's right to survival. "Necessity" is treated as an imperative. It is an ethical position with regard to the limits of the law in human association. Immanuel Kant also elaborates this theme as a part of his discussion of law and morality in the civil state.

\section{B. Immanuel Kant, Ontology, Morality, and the Law}

The discussion of "necessity" in the writings of Immanuel Kant takes place within a broad context, linking the Kantian epistemology, ontology, and claims regarding civil society. The ontology of Immanuel Kant asserts that the human being is both phenomenal, part of the physical world of experience, and noumenal, part of the "realm of the mind." (Kant 1977b, 196-198) As a part of the physical environment a person is subject to all the laws which govern the interaction of objects in physical space. However, Kant suggested the possibility that the individual, having the power of transcendental reason, has the capacity for thought which is independent of the deterministic features of the phenomenal world.

This seemingly abstract philosophic notion is very significant with respect to Kant's claim about the possibility of freedom and morality. If the power of the will operates in a realm outside the determinism of the phenomenal world then the freedom of the will to direct the body's actions may be assumed. If there is an undetermined element in the make-up of the human being, said Kant, the individual "may" be provided with the possibility of autonomous action.

Here it should be noted that Kant does not claim he can "prove" the autonomy of the will, only that the possibility for it exists. He does, however, assert emphatically that, "...the principle of autonomy is the sole principle of morals." (Kant 1977b, 188) Kant argues that without freedom no moral accountability is possible. If individuals do not choose their actions they cannot be held morally accountable for those actions. When a person is not free to do otherwise, that person bears no responsibility for the outcome of an act. So while freedom of the will cannot be proven within the Kantian scheme, it must be assumed if morality is to have any meaning. 
For Kant, the interaction of individuals creates problems. If human beings are truly free, the social environment in which they pursue their happiness will generate "antagonisms." (Kant 1977c, 429) As both reason and impulse, selfish egoism would reign unchecked should some mechanism to control the impulsive side of the human character not be present. Kant concluded that in society man is in need of a "master." (Kant 1977a, 122) The aggression and selfishness in human nature can be mitigated if reason is used to keep impulse under control. (Kant 1977a, 119) Reason allows for the creation of an external body of rule which can serve to regulate social interaction. This regulation of freedom is designed to produce the maximum amount of freedom that can be shared by all. (Kant 1977a, 121)

Kant indicated that he did not believe every problem could be solved by creating laws. No matter how perfect a system of laws, the perfectibility of the human being is still in doubt. As Kant stated, "...a complete solution is impossible. One cannot fashion something absolutely straight from wood which is as crooked as that of which man is made." (Kant 1977a, 123) The best that one can hope for is an approximate solution. That consists of creating an external body of laws that will regulate the behavior of individuals in their social interactions.

Here Kant is making a very specific claim regarding the role of law in civil society. Freedom of interaction is to be maximized for everyone equally. The role of the law is to deter those who would subvert the attainment of a common level of freedom for all. The use of force, that is organized and legitimated as the externalization of human reason, serves a deterrent function in society. Those that would inhibit the freedom of others would be, according to Kant, deterred by the threat of punishment. Law, and the collective force that it represents, checks the impulsive and egoistic elements in human nature. Only when the natural antagonisms among people are checked can mankind reach its fullest potential.

A functioning set of laws designed to regulate human intercourse is essential to civil society. The collection of those laws Kant referred to as a "civil constitution." Kant stated that joining into civil society is the first duty of those who cannot avoid having mutual influence on one another. (Kant 1977c, 415) A union of people in a commonwealth involves the externalization of duties into a formal set of standards based on the principle of freedom. (Kant 1977c, 415) Kant is emphatic with regard to the standard that is to govern the conduct of individuals in civil society. Kant declared that people should always act to treat others as "ends" not merely as means. Thus Kant has linked the idea of personal obligation and morality to the formulation of law in civil society.

In Part I of The Metaphysics of Morals, a section entitled The Metaphysical Elements of Justice, Kant explored this further by asserting what he called the "Universal Principle of Justice."

Every action is just if its maxim is such that the freedom of the will of each can coexist with the freedom of everyone....(Kant 1965, 35)

This statement contains a variety of elements relevant to the notion of freedom in Kant's moral and political philosophy. The primary characteristic of justice is the maintenance of freedom in social intercourse. It is also important to note that Kant makes no reference to the content of interaction or of its goals. In fact, he specifically states that the content of social interaction is not the specific concern of justice. "[T]he content of justice does not take into consideration the matter of the content of the will ..." (Kant 1965, 34) Only the form of interaction is relevant for Kant. 
Relations must be such that the participants share a common and equal level of freedom in the conduct of their affairs.

Rights and duties within the state ultimately derive from the principle of freedom. (Kant 1977c, 415) The state has the role of both legal adjudicator and coercive apparatus in the maintenance of freedom. The strategy of civil society is to create an external set of duties, "publiccoercive law," in which every person's rights are secured against interference from any other person in the society. (Kant 1977c, 415) The state, said Kant, "is a union of men under juridical laws." (Kant 1935, 182)

The state, as a collection of laws, is a legitimate instrument of coercion if it uses its power for the maintenance of the maximum level of freedom that all the members of society can share. (Kant 1965, 36-39) The state's system of justice, positive law, emerges in order to protect each citizen from the natural antagonisms that arise as individuals seek to maximize their happiness in the social environment. (Kant 1977c, 416-417) The state has both the obligation and the force to compel compliance to the laws which protect the freedom of all.

\section{C. "Necessity" and the Deterrent Value of the Law}

Kant did not leave the discussion on the functions of law here. In the appendix to Metaphysical Elements of Justice he suggested two caveats to the ability of the state to compel human action. There are two areas of human interaction where justice, as the state's use of legitimate coercive force, does not serve its intended purpose. In these two areas the coercive power of the state cannot, logically, be effective in regulating human behavior or protecting human freedom.

The first of these exceptions to the role played by the law in regulating human interaction is what Kant called the "right of equity." The second he called the "right of necessity." In discussing the right of equity, Kant asserted that the law is not applicable to issues involving the subjective moral conscience of a person. For example, in establishing a private contract between two individuals all the possible contingencies may not be foreseen. In such a case one of the contracting partners may have to appeal to the fairness or sense of "equity" in the other. Kant defined this appeal to personal conscience as "right without coercion." (Kant 1965, 39) The judicial system cannot oversee all the possible facets of interaction, therefore appeals to "fairness" will be part of the interaction of individuals. As part of the general discussion of morality, Kant believed that a general "moral sentiment" can be engendered in individuals through education and moral training. The process of moral training will serve to regulate what is "fair," even when the law cannot be directly engaged.

Kant's second caveat to his theory of justice, however, is far more important for the consideration of the state's responsibilities with regard to its citizenry. Kant defined the right of necessity as essentially "coercion without right." (Kant 1965, 39) Stated directly, "necessity" is the right to take any action necessary in order to preserve one's own life.

By "necessity" Kant meant considerably more than a notion of self defense. The right of self defense implies a right to preserve one's life if that life is threatened by another. The right of necessity, on the other hand, is the right to take action that causes harm or death to another, even to a person who is not a direct threat to one's own life and safety.

This imagined right is supposed to give me 
permission to take the life of another person when my own life is in danger, even if he has done me no harm. (Kant 1965, 41)

Necessity involves the interaction of two or more people. According to Kant's discussion of civil society, the law is essential for the regulation of that interaction. Kant asserted, however, that when necessity is the issue, the law is ineffective as a restraint on human behavior.

It is quite obvious that this conception implies a self-contradiction within jurisprudence,,.. and $]$... belongs only to ethics. (Kant 1965, 41)

The right of necessity is an issue that can only be addressed in an ethical context. But Kant did not suggest that acts done out of necessity are ethical or enjoy insulation from moral condemnation. The contrary is actually the case. An action done out of necessity may be immoral and still not be appropriately subject to punitive legal action. This is the case because law cannot logically deter actions that are generated out of fear for one's survival.

Necessity is invoked in a context in which the deterrent function of the law is ineffective. Kant suggested that when faced with the imminent threat of losing one's life there is nothing that the coercive apparatus of the state can do to compel a particular type of behavior. The law, and the force of punishment, can have no effect on an individual's behavior where necessity is at issue. The law cannot serve as a check on moral or social injustices. The threat of punishment has no meaning if there is no penalty which can be worse than certain death. The pursuit of selfpreservation, while it may violate the legal statutes of written law, cannot logically be punished. Kant was very clear on this issue.

A penal law applying to such a situation could never have the effect intended, for the threat of an evil that is still uncertain cannot outweigh the fear of an evil that is certain. Hence, we must judge that, although an act of self-presentation through violence is not inculpable, it still is unpunishable...(Kant 1965, 41)

The law cannot apply to an action done out of necessity because it contains no effective threat of coercion behind it.

Necessity is described as an important exception to the role positive law plays in maintaining and protecting a common quantity of freedom within the state and society. The state and its laws are designed to protect the freedom of each of society's members. The state cannot function effectively in circumstances where the adherence to its laws cannot be guaranteed through the use of sanctions. "Necessity" is, logically, a constraint on the effectiveness of the law.

In raising the issue of the conditions required for the "effective" law, Kant has provided a context for questioning the state's responsibilities on issues of social policy. What conditions must be present in order for the law to function effectively? Under what conditions can the law fulfill its purpose of protecting the freedom of the citizenry?

Kant realized that not all individuals can be expected to be "good." Kant asserted, however, that through a system of laws individuals can be compelled to respect the rights of others. But the conditions for that compliance must first exist. The legal system's intended purpose of protecting 
the freedom of the citizens cannot be fulfilled under conditions in which necessity is legitimately involved. The state cannot fulfill its function of compelling individuals to respect the freedom of others unless the state's system of laws are sufficient to deter individual egoism at the expense of other's freedom. Laws have no power to compel when "necessity" is at issue.

The problem necessity generates for the functioning of the law raises questions about the role of the state in a very broad social context. If necessity inhibits the effective performance of the law, and effective laws are necessary in order to protect the citizens, then the function of the state must go beyond acting simply as the repository for collective force. The state must act to create the conditions in which the citizens are secure from violence. In order to do this the state must assure that it has created the conditions in which the law is an effective mechanism for deterring violence. The state must seek to minimize necessity as a motivation for behavior because action generated out of necessity takes place outside of the arena in which the law is effective.

Social welfare is the state's mechanism for removing economic necessity as a motivation for action. Welfare assists in creating the conditions in which the "rule of law" is meaningful and effective. Therefore, the state's legal and coercive functions are inseparable from its welfare functions.

\section{Necessity and United States Welfare Policy A. Obedience, Law, and Coercion}

The determination of who is responsible for the condition of the poor is only one question in the discussion of social welfare. As Aristotle realized 2300 years ago, an equally important issue for the state is how to maintain an effective set of legal institutions for the maintenance of both freedom and social order. Politics is the process of finding that formula in which individuals can possess both autonomy of action and security in a collective environment.

Kant made a logical assertion regarding the conditions necessary for a good political life based on his premises about human nature and the role of the state. In Kant's analysis, the concept of necessity negates the effective functioning of the state's legal apparatus. However, if one accepts the Kantian view that human beings are, in part, egoistic, an effective legal order is essential if the state is to protect its citizens. To the extent that social welfare removes economic necessity as the cause of violent activity, it enhances the security of the population.

Further, there is a logical inference about the state that must be made explicit. The state claims a monopoly on the legitimate use of force. It is the state which holds people accountable for their actions through formal legal institutions and through a system of punishments. Therefore, the state must address the conditions which influence the effective functioning of those institutions. An absolute condition of want reduces the effectiveness of legal institutions. It is the state's responsibility to ensure that it provides the conditions in which the law can be effective. In other words, the state must ensure that all of the citizens have the necessities of life.

The liberal tradition suggests that people enter into the social contract in order to protect life, liberty, and property. It is, therefore, the state, not voluntary organizations, that has the welfare responsibility. An attempt to relegate the responsibility for welfare to voluntary social organizations violates the social contract. By failing to provide for the conditions necessary for the protection of public order the state has failed to meet its obligation to provide security to the population. 
Proponents of the ethics of personal responsibility, including the recent neoconservative writers on the welfare state, stress the state's role in maintaining an orderly society. The state, they argue, has a role in securing the obedience of the population. However, this approach is extremely myopic and at its core self-contradictory. The desire for order and compliance to state authority does nothing to secure the external conditions necessary for the rule of law. A call for "personal responsibility" is not sufficient to ensure that compliance to legal prescriptions will be compelling. The constant drumbeat of the neoconservative, that a return to ascetic Protestant values will solve America's social crisis, is not only destined to fail, but also can only result in a erosion of civil liberties in a modern multicultural setting. The irony of the situation is that the welfare state, the object of attack by the proponents of "personal responsibility," may actually serve to increase both the viability of personal responsibility and order by creating the conditions in which compliance with the law can be expected.

Law and order can have legitimacy only after the essential needs of the population have been guaranteed. The sequence of this formula is essential. Rule of law can only come after the individual is removed from an absolute condition of want. The state, therefore, has a prior responsibility to guarantee what is necessary if it is to demand compliance with its legal statutes. "Necessity knows no law." But the rule of law is the essential characteristic of the state. It is the state that must act to ensure compliance with its rules. It can do this legitimately only if it creates the conditions for that compliance.

The only alternative is coercion. The state could choose to bring about compliance through illegitimate means, the use of raw power, as a substitute for fulfilling its obligations within the social contract. This is the real danger presented by the neoconservative critique of the welfare state; the creation of a permanent "wanting class," whose members fill the jails, as the state's responsibility remains unfulfilled. Ultimately, the dismantling of the welfare state can only produce the long term consequence of breaking down the conditions for public order.

It is here that Kant's reasoning offers some insights into the current social crisis in the United States. According to the Sentencing Project, in 1991 the number of people in prison or held in pretrial detention hovers around one million, an increase of over two hundred percent since 1980. Despite the "get tough" attitude of law enforcement, violent crime continues to rise. Applied to the current situation in the United States, the Kantian logic suggests that the failure of the threat of state violence to curb the aggressive acts of rational actors may have its roots in the perception that there is "nothing to lose" in the commission of a violent act. An underclass that is motivated by a real or perceived condition of necessity will not be deterred ay any enforcement approach to public order. Any such strategy, the logic suggests, will ultimately be ineffective.

Within the Kantian framework violence is seen as a symptom, not a cause, of social crisis. In the United States there appears to be a failure of policy makers to understand that the law alone is not always sufficient to solve a complex public problem. Effective laws require more than expanded enforcement. The conditions must also exist for that law to be effective.

Welfare is an essential means to the goal of public order. Welfare, as a collective mechanism to inhibit "necessity" as a cause of social action is indispensable to the enhancement of everyone's security. Understood in this way, the attempts to cut social welfare programs appear irrational, threatening the viability of the law and the stability of the society. 


\section{Conclusion}

The classical liberal ideology, molded by strong ascetic Protestant roots in the United States, has created a political culture that tends to identify a person's social and economic well being as a result of individual choices. Within this cultural framework, the need for personal assistance is, therefore, associated with laziness or immorality, despite evidence to the contrary. Opponents of welfare need only conjure up the images of those who have begun with nothing and made vast fortunes in order to evoke the perception that all welfare recipients are social parasites. The opponents of social welfare have this aspect of American culture, accurate or not, to rationalize their claims.

The significance of the "necessity" discussion is that it makes the argument that centers on "personal responsibility" largely irrelevant for the question of social policy. The responsibility question is an irresolveable ontological quagmire. The focus on necessity suggests there is a more important issue that needs to be addressed about the state's responsibilities under the social contract. Central to the state's duties is the security of the citizens. Action which is motivated by necessity threatens that security. The state must actively seek to reduce the role played by necessity in public life in order to make the population more secure. Social welfare is essential to that end. There is an increasing need to understand that the welfare state is supported by principles contained within the liberal tradition at a time when liberalism's individualism is being employed to justify the pruning of social assistance.

What is unique about Kant's discussion of "necessity" in formulating support for the welfare state is that the argument can be made with an appeal to self interest. Kant would agree with other liberals, such as T. H. Green, that the state has a responsibility to all of its members because of their worth as individuals. However, the stress in Kant on what is necessary for the effective functioning of the law allows for the welfare discussion to move beyond Green's identification of the "morally good" with the "common good." (Green 1969, pp. 251, 255) Green requires moving beyond the idea of self interest. Focusing on the necessity discussion in Kant requires no such universalism to justify support for the welfare state. Is it not in everyone's self interest to live within a state in which the laws are an effective deterrent to violent behavior?

If that is the case, then the strategy of those seeking to expand welfare should be clear. The electorates understanding of self interest must be expanded to include the elimination of necessity as a cause for social action. It must be understood that everyone in society has their security enhanced by assisting in the economic security of the poor.

\section{Bibliography}

Aristotle. 1977. The Politics. Ed. and Trans. Ernest Barker. London: Oxford University Press.

Dolbeare, Kenneth. 1984. American Political Thought. Chatham, New Jersey: Chatham House.

Gordon, Colin. 1991. "New Deal, Old Deck: Business and the Origins of Social Security, 19201935." Politics and Society. 19 (2); 165-207. 
Green, Thomas Hill. 1969. Prolegomena to Ethics. New York: Thomas Crowell

Hobbes, Thomas. 1978. The Leviathan. Indianapolis: BobbsMerrill.

Kalberg, Stephen. 1991. "The Hidden Link Between Internal Political Culture and Cross-national Perceptions: Divergent Images of the Soviet Union in the United States and the Federal Republic of Germany." Theory, Culture, and Society. 8; 31-55.

Kant, Immanuel. 1935. "The Philosophy of the Law." Readings in Recent Political Philosophy. Ed. Margret Spahr. NY: Macmillan.

Kant, Immanuel. 1965. The Metaphysical Elements of Justice. Trans. John Ladd. Indianapolis: Bobbs-Merrill.

Kant, Immanuel. 1977a. "Idea for a Universal History." The Philosophy of Kant. Ed. Carl Friedrich. NY: Modern Library.

Kant, Immanuel. 1977b. "The Metaphysical Foundations of Morals." The Philosophy of Kant. Ed. Carl Friedrich. NY: Modern Library.

Kant, Immanuel. 1977c. "Theory and Practice." The Philosophy of Kant. Ed. Carl Friedrich. NY: Modern Library.

Levy, Michael. 1988. editor. Political Thought in America. Chicago: Dorsey Press.

Mead, Lawerence. 1986. Beyond Entitlement: The Social Obligation of Citizenship. NY: Free Press.

Meehan, Eugene J. 1973. "Science, Values, and Policies." American Behavioral Scientist. 17(1): 53-100.

Murry, Charles. 1984. Losing Ground. NY: Basic Book.

Offe, Claus. 1987. "The Structural Foundations of Neoconservative Political Opportunities." Political Theory. 15(4): 501-537.

St. Thomas Aquinas Summa Theologica. II-II, Q. 66., Art. 4.

Wolin, Sheldon. 1987. "The Political and Theoretical Connections Between Staatsraeson and Wohlfahrtsstaatsraeson." Political Theory. 15(4):467-500. 